\title{
Anarchy and International Law: The Approaches of Hedley Bull and Noam Chomsky
}

\begin{abstract}
Jean Allain*
Beyond the pejorative, anarchism - if considered at all - is seen as being antithetical to the Statist system and that which regulates it: international law. While scholars of international law have shied away from labelling it as such, the international legal order, lacking as it does central law creating, determining, and enforcement mechanisms, and being based on cooperation as opposed to coercion, is quintessentially anarchistic. This understanding, it should be noted, has not escaped theorist of international relations; in fact, it is the opposite. As Hedley Bull relates, whereas "men within each state are subject to a common government, sovereign states in their mutual relations are not. This anarchy it is possible to regard as the central fact of international life and the starting-point of theorising about it"1. This "anarchy problematique' continues to this day to play its part in seeking to understand the manner in which international relations functions in the absence of a central government and the manner in which cooperation manifests itself within an anarchical framework. Yet, this fundamental discussion finds little or no place in the discourse of international law, where more often than not anarchy is the pedestrian synonym of disorder; this, at the expense of its theoretical understanding as an international society based on cooperation, void of central authority.

That international legal scholars think of the international society as being anarchistic is rather rare. Anthony Clark Arend explains the gap between international relations theory and international law:
\end{abstract}

Many international legal texts begin with a discussion of the 'sources' of international law - the ways in which legal rules are created. These works immediately delve into the international legislative process without first taking into account the nature of the international system itself. This approach is undoubtedly troubling to many international relations theorists. For them, it would seem impossible to understand how rules are produced unless the larger framework of international affairs is fully discussed. [...]

In fairness to international legal scholars, this failure to explore deeply the nature of the international system may be due less to a lack of rigor than to a long tradition of shared assumptions among legal scholars about the nature of the system ${ }^{2}$.

Manifestations of these shared assumptions are to be found, for instance, in Antonio Cassese's text book, wherein he writes of the "relations between the States comprising the international community remains largely horizontal". While acknowledging cooperation in an era of globalisation has meant the development transnational institutions, Cassese notes that "[r]elative anarchy still prevails at the level of central management",3, though it is unclear by the wording or context whether Cassese is speaking of anarchy in the pejorative sense or not. Thus shared

\footnotetext{
Professor in Public International Law, School of Law, Queen's University of Belfast. Extraordinary Lecturer, Centre for Human Rights, Faculty of Law, University of Pretoria.

1 Hedley Bull, "Society and Anarchy in International Relations", Kai Alderson and Andrew Hurrell (eds.), Hedley Bull on International Society, 2000, p. 77.

Anthony Clark Arend, Legal Rules and International Society, 1999, p. 42. Arend goes on to consider the various schools of international theory such as structural realist, constructivist, etc. and demonstrates that none of the schools challenges the centrality of anarchy to the functioning of the international system.

Antonio Cassese, International Law, 2005, p. 5.
} 
assumptions mean that Anthony D'Amato can speak of anarchy in the pejorative "Anarchy could bring down the demise of the ILS [international legal order]" - rather than as the very basis of that international legal order. ${ }^{4}$ This trope of anarchy as chaos within the discourse of international law persists. Consider Maria Gavouneli who, in the pages of the European Journal of International Law, points to the emanate jurist of the last century, Nicolas Politis stating that that he "argued in 1935 that the law of neutrality was obsolete, a product of the international anarchy of the times". In reference to this assessment, Gavouneli states that 'the situation [...] is today very different. Although international anarchy has not yet entirely disappeared, it is no longer the dominant trait $[\ldots]$ of our era".

This study, by contrast, contemplates international law in two manners in which an anarchist might consider interesting: first, as a legal system which governs an anarchical society as described by Hedley Bull in line with the English School of International Relations which sees in international law an institution of international order; and second, as a manifestation of a State system which, though illegitimate, can be utilised as Noam Chomsky does, for tactical reasons to demonstrate its inconsistencies and thus weakening the system with the ultimate aim being its implosion. For those interested in the approach of Bull, this piece seeks to highlight the lack of engagement by international legal scholars with anarchy as the fundamental nature of international law. For those interested in Chomsky's approach, the piece raises the possibility of using international law as a means of thinking about what a domestic legal order might resemble, functioning on anarchic principles. Before turning to consider these two approaches, the study first considers libertarian socialism as a theoretical stream of anarchism so as to draw out the parallels as between its vision of a social system and the manner in which the international community of States actually co-exist.

\section{Anarchism}

Putting aside international relations theorists for the moment, those who have engaged most with the notion of anarchism have been social thinkers interested in considering a domestic order void of the State. Anarchism, it may be said, is a rather large tent which covers various derivatives of a social stream. The etymology of the word is from the Greek, meaning the absence of authority or government. For David Miller, anarchism is not an ideology, but an intersection of ideologies which, emanating from the force unleashed during the French Revolution, demands that any and all institutions, above all else the State, be required to continually justify themselves as against basic principles, be they "natural rights, social utility, human self-realization, or whatever". ${ }^{\circ}$ For Daniel Guérin, anarchism "is really a synonym for socialism. The anarchist is primarily a socialist whose aim it to abolish the exploitation of man by man. Anarchism is only one of the streams of socialist thought, that stream whose main components are concern for liberty and hast to abolish the State".

\footnotetext{
4 Anthony D'Amato, "International law as a Unitary System", in David Armstrong (ed.) Routledge Handbook on International Law, 2009, 106.

5 Maria Gavouneli, “Neutrality - A Survivor?”, European Journal of International Law, Vol. 23, 2012, p. 267.

$6 \quad$ David Miller, Anarchism, 1984, p. 3.

7 Daniel Guérin, Anarchism, 1970, p. 12.
} 
It should be emphasised that the glue which holds the various threads of anarchism mentioned is the anarchist antagonism towards the State, which is seen as authoritarian and unrepresentative. Miller explains that for anarchists, the State should be replaced by a "new form of social organization". The State is not inevitable, but is a construct of post-Renaissance Europe which is characterised by the following:

First, the state is a sovereign body, in the sense that it claims complete authority to define the rights of its subjects - it does not, for instance, allow subjects to maintain customary rights which it has neither created nor endorsed. Second, the state is a compulsory body, in the sense that everyone born into a given society is forced to recognize obligations to that state that governs that society - one cannot opt out of these obligations except by leaving society itself. Third, the state is a monopolistic body: it claims a monopoly of force in its territorial area, allowing no competitor to exist alongside it. Fourth, the state is a distinct body, in the sense that the roles and functions which compose it are separate from social roles and functions generally, and also that the people who compose the state for the most part form a distinct class - the politicians, bureaucrats, armed forces and police.

Anarchists make two charges against the State $[\ldots]$ - no institution with the four features listed above - could have come into existence without something akin to an act of piracy on the part of those who would become its rulers. For why would men freely surrender their rights to such a Leviathan? [...]

But the greater volume of anarchist criticism is aimed at what states do when they are allowed to exist. [...] first, the state is a coercive body, which reduces people's freedom far beyond the point required by social co-existence. It enacts restrictive laws and other measures which are necessary, not for the well-being of society, but for its own preservation. [...] Second, the state is a punitive body, which inflicts cruel and excessive penalties on those who infringe its laws, whether or not the laws are justified in the first place. [...] Third, the state is an exploitative body, which uses its powers of taxation and economic regulation to transfer resources from the producers of wealth to its own coffers, or into the hands of privileged economic groups. Finally, the state is a destructive agency which enlists its subjects to fight wars whose only cause is the protection or aggrandisement of the state itself. ${ }^{8}$

Mention of the Leviathan is instructive here, as one of the most influential anarchist theorists, the Russian Peter Kropotkin (1842-1921) challenged the Hobbesian notion of a state of nature, where a type of social Darwinism can only be tamed by the introduction of the State to provide security. Kropotkin's book Mutual Aid demonstrates, as opposed to Darwin's theory, that evolution is not a fratricidal struggle for existence but that evolution of animals manifests itself in "a struggle against all natural conditions unfavourable to the species". Kropotkin's understanding of evolution is based on progressive development through cooperation:

The animal species, in which individual struggle has been reduced to its narrowest limits, and the practice of mutual aid has attained the greatest development, are invariably the most numerous, the most prosperous, and the most open to further progress. The mutual protection which is obtained in this case, the possibility of attaining old age and of accumulating experience, the higher intellectual development, and the further growth of sociable habits, secure the maintenance of the species, its extension, and its further progressive evolution. The unsociable species, on the contrary, are doomed to decay. ${ }^{9}$

Kropotkin follows this study with an essay entitled: The State: its Historical Role, which George Woodcock considers the final chapter of Mutual Aid. In it Kropotkin fears that authoritarian socialism of the Marx and Lenin variety will quash anarchist tendencies in the coming social revolution. He demonstrates the manner in which the

$8 \quad$ David Miller, Anarchism, 1984, p. 7.

9 Peter Kropotkin, Mutual Aid: A Factor of Evolution, 1902, p. 147. 
State has imposed itself by force against those that have lived in cooperative harmony. He writes that throughout "the history of our civilisation, two traditions, two opposed tendencies, have confronted each other: the Roman and the popular traditions, the imperial and the federalist, the authoritarian and the libertarian." 10 For Kropotkin the choice is clear, humanity can only prosper through cooperation devoid of the State:

Either the state forever, crushing individual and local life, taking over in all fields of human activity, bringing with it wars and its domestic struggles for power, its palace revolutions which only replace one tyrant by another, and inevitably at the end of this development there is only ... death! Or the destruction of the state, and a new life starting again in thousands of centres on the principle of lively initiatives of the individual and groups and that of free agreement. ${ }^{11}$

To understand 'anarchism' as a social theory, one must first rid oneself of the baggage of 'anarchist-as-bomb-thrower', and distance oneself from 'propaganda of the deed'. While this has been an undeniable element of anarchism, it has come to represent anarchy at the expense of a mainstream understanding of a social system based on libertarian socialism. Yet, it should come as little surprise that 'anarchism' has instilled itself within the public conscience as being something to rail against when it seeks the ultimate removal of the State as the basis of society. Lesser challenges, it may be said, have brought the wrath of States, whereby they have reacted decisively in seeking to counter any threat to the Statists system, be it the German orchestrated coup d'état to impose the Bolsheviks on revolutionary Russia in 1917; the Fascist and Communist forces fighting against the anarchist in Spain during the 1930s; or the current 'War on Terror' against those who seek to replace the State system with the religiously-based Dar el-Islam. Thus, it should come as little surprise that as anarchism seeks to displace the State that the Statist system has sought - rather successfully - to disparage it by having it equated in the public consciousness as being synonymous with chaos and lawlessness.

Turning to the question of law; ordinarily an anarchist would disparage a legal system, be it domestic or international in character. For anarchist thinkers, as a nonrepresentative institution which maintains its control through coercion, the State and its legal system is antithetical to the fundamental tenets of anarchism: societies based on consent and cooperation which are non-hierarchical and non-authoritarian. The legal system plays its part in maintaining that status quo. Kropotkin considered that there existed, at the domestic level, three types of laws; those that protect property, those protecting people, and those protecting government. With regard to the protection of property Kropotkin saw law as simply an attempt by the few to monopolise the resources belong to all and that court cases dealing with issues of property are "nothing but quarrels between monopolists - two robbers disputing over their booty". As for laws protecting the person, Kropotkin saw criminal law all but disappearing in the wake of the establishment of an anarchic society where protecting property laws no longer exists. Where human being are allow to reach their full potential and to develop as they wish, they "will procure him so many enjoyments that he will not seek to poison them". Finally, with regard to laws protecting the government, he notes:

We know very well - anarchists have often pointed out in their perpetual criticism of various forms of government $[\ldots]$, is to protect and maintain by force the privileges of the classes in possession. [...] A good third of our laws - and each country possesses taxes, excise duties, the

10 Martin Miller (ed.) Peter Kropotkin, Selected Writings on Anarchism and Revolution, 1973, p. 262.

11 Id., p. 264. 
organization of ministerial departments and their offices, of the army, the police, [etc.], have no other end than to maintain, patch up, and develop the administrative machine. And this machine in turn serves almost entirely to protect the privileges of the possessing class. ${ }^{12}$

Yet, as we shall see, at least in two instances there has been an engagement with law at the international level: on the one hand anarchism is considered as the basis of the international system and consideration is given to the role which international law plays within that order; and on the other hand, that international law is utilised as against itself to weaken the Statist system in favour of building a societal system on the tenets of a libertarian socialist understanding of anarchism. Thus we now turn to international law, manifest in the approaches of Hedley Bull and Noam Chomsky.

\section{Hedley Bull}

Hedley Bull (1932-1985) was an Australian academic who was the leader of the socalled 'English School of International Relations' during the latter half of the twentieth century. He taught at the London School of Economics and Political Science from 1955 to 1965 before taking up a post of Director of the Arms Control and Disarmament Unit of the British Foreign Office for a short period of time. From 1967-1977 he was Professor of International Relations at the Australian National University, before taking up the Montague Burton Chair of International Relations at the University of Oxford, a post he held until his death.

\section{Bull on Anarchism}

The English School of International Relations, led by Martin Wight in the aftermath of the Second World War, coalesced around the British Committee on the Theory of International Politics established in 1959 and found its fullest expression in Bull's 1977 The Anarchical Society: A Study of Order in World Politics. That tradition, which remains a live one, receiving its most recent expression in the writings of Andrew Hurrell, the current holder of the Montague Burton Chair. ${ }^{13}$ This school of thought sees international relations as a system which has been established based on institutions and rules which function in an anarchic manner as between sovereign States to create an international order. The English School thus takes anarchy seriously, as the starting point for theorising about international relations and, to that extent, sees international law as an institution which plays a central role in allowing for cooperation to manifest itself in common rules and values.

Bull takes the position that international relations could best be understood beyond the dichotomy of realism/idealism, arguing that international relations is best represented by a society of States existing in an anarchic manner, in consonance with a Grotian worldview. That is: a Grotian conception of an international society which finds place between a Hobbesian state of nature and a Kantian universal society. For Bull though, the "modern international system in fact reflects all three of the elements singled out: respectively, by the Hobbesian, the Kantian and the Grotian traditions"14.

\footnotetext{
12 Peter Kropotkin, "The Uselessness of Laws", George Woodcock (ed.), The Anarchist Reader, 1977, pp. 111, 112, 113. Emphasis in the original.

13 See Andrew Hurrell, On Global Order: Power, Values, and the Constitution of International Society, 2007.

14 Hedley Bull, The Anarchical Society: A Study of Order in World Politics, 1977, p. 41
} 
Although Thomas Hobbes wrote about the securing domestic peace in the context of the English Civil War, his writings have been used as a basis for the Realist school of international relations. Hobbes' solution to domestic conflict is to provide for an all-powerful overarching Leviathan - the State - which imposes its will and thus moves society from a state of nature - which is for Hobbes a state of war - to a state of peace. ${ }^{15}$ Bull notes that individuals, "in Hobbes' account, are driven to escape from the state of nature by submitting to a sovereign power that will hold them in awe [... and thus agreeing] with the sovereign to submit themselves to him in return for protection". Yet, Bull states that the "analogy between the condition of states in the international anarchy and the condition of individual persons living without government is not taken by Hobbes to what, on some views at least, is its logical conclusion". That is, that if the move from the state of nature a state of peace requires an over-arching Leviathan, then the same argument should hold for States themselves. As Bull relates, the "idea of a covenant among sovereigns does not seem to have occurred to Hobbes. Still less does it occur to him, as it does not to any of the contract theories in the long line from Plato to John Rawls, to consider the possibility of a contract of world government among all individual persons of the world"16.

By contrast to the Hobbesian conception of international relations as a continuous conflict between atomised States; Immanuel Kant puts forward as a basis of perpetual peace, the need for the establishment of a universal State. This perspective, Bull relates, "would arise as the consequence of a social contract among states", and thus "would be a universal republic or cosmopolis founded upon a form of consent or consensus" ". For Kant, a Leviathan is to be established by agreement; herein the sovereign authority provides security and order. Bull argues that such an approach faces a dilemma, wherein description of international relations and the prescription for its improvement "are inconsistent with one another". While action "within the context of continuing international anarchy is held to be of no avail", perpetual peace is to take place by the establishment of an "international social contract" within that same said international anarchy ${ }^{18}$.

For Bull, the international system has at times reflected the Hobbesian and, at times, the Kantian traditions, yet it is best understood conceptually as an international society based on solidarity. This conception of international society underlies "a great deal of the theory and practice of international relations since the First World War":

[Its] imprint may be traced in the Covenant of the League of Nations, the Paris Pact, the United Nations Charter and the Charter of the International Military Tribunals at Nuremberg. It is widely taken to contain within itself an adequate formula for orderly and just international conduct, such

15 Note also that Bull sees the state of nature more in tune with Locke than Hobbes:

If, then, we are to compare international relations with an imagined, pre-contractual state of nature among individuals men, we may well choose not Hobbes's description of that condition but Locke's. Locke's conception of the state of nature as a society without government does in fact provide us with a close analogy with the society of states. In modern international society, as in Locke's state of nature, there is no central authority able to interpret and enforce the law, and thus individual members of the society must themselves judge and enforce it. Because in such an society each member of its is a judge in his own cause, and because those who seek to enforce the law do not always prevail, justice in such a society is crude and uncertain.

See $I d .$, p. 48.

16 Hedley Bull, "Hobbes and the International Anarchy", Alderson and Hurrell, op. cit. n.1, pp. 195196.

17 Hedley Bull, op. cit. n. 14, p. 253

18 Hedley Bull, "Society and Anarchy in International Relations", Alderson and Hurrell, op. cit. n.1, p. 92. 
that the disparity between and the actual course of events since 1919 may be ascribed to the failure of it states or statesmen to behave in accordance with it, rather than to its own inherent defects ${ }^{19}$.

This, Bull terms, the Grotian conception of an international society, one whose

prescription for international conduct is that all states, in their dealing with one another, are bound by the rules and institutions of the society they form. As against the view of Hobbesians, states in the Grotian view are bound not only by rules of prudence or expediency but also by imperatives of morality and law. But, as against the view of the universalists, what these imperatives enjoin is not the overthrow of the system of states and its replacement by a universal community of mankind, but rather acceptance of the requirements of co-existence and co-operation in a society of states ${ }^{20}$.

For Bull, the work of Grotius establishes beyond the Hobbesian and Kantian traditions an overarching paradigm from which to understand international relations, that is, the idea of an international society: "the notion that states and rulers of states are bound by rules and form a society or community with one another, of however rudimentary a kind". "For better or worse", Bull writes, this idea of an international society as a normative order is "the constitutional principle in terms of which international relations today are in fact conducted". ${ }^{22}$ In essence, although De Jure Belli ac Pacis was published in the seventeenth century, its conception of the international society is manifest in the order which emerges three hundred years later in institutions such as Covenant of the League of Nations and later the United Nations Charter, as well as the Statute of the International Criminal Court and the principles they embody. In other words, that in their international conduct States are bound by the "rules and institutions of the society they form"; and by an "acceptance of the requirements of coexistence and co-operation in the society of states". ${ }^{23}$ While the idea of the international society existed in the time of Grotius, it was rudimentary and touched limited areas of intercourse. By contrast today, while rules govern a vast range of such intercourse, the "underlying idea, the normative and institutional framework upon which these changes have been constructed, is recognizably the same". ${ }^{24}$ That, in Bull's words, under the Grotian conception of the international order:

states and the rulers of states in their dealing with one another were bound by rules and together formed a society. On the one hand princes and peoples had indeed become independent of one another and of central authorities and were sovereign. But on the other hand they were not in a state of nature, but part of the great society of all mankind, magna communitas humani generic. Even without central institutions, rulers and peoples might constitute a society among themselves, an anarchical society or society without government. ${ }^{25}$

As Suganami notes, "it may not be an exaggeration to say that [Bull] is one of the best-known critics of the domestic analogy". ${ }^{26}$ Bull's approach to considering an international society as being anarchical is to first reject the challenge of a domestic

19 Hedley Bull, "The Grotian Conception of International Society”, id., p. 96.

20 Hedley Bull, op. cit. n. 14, p. 27.

21 Hedley Bull, "The Importance of Grotius in the Study of International Relations", Hedley Bull, Benedict Kingsbury and Adam Roberts (eds.), Hugo Grotius and International Relations, 1995, p. 71.

22 Id., p. 93

23 Hedley Bull, op. cit. n. 14, p. 27.

24 Hedley Bull, "The Importance of Grotius in the Study of International Relations", Bull, Kingsbury and Roberts, op. cit. n. 21, p. 73.

25 Id., p. 72.

26 Hidemi Suganami, The Domestic Analogy and World Order Proposals, 1989, p. 11. 
analogy, not because he rejects the notion that individuals can not exist in an anarchic society, but that "states form a society without government reflects features of their situation which are unique"; that "anarchy among states is tolerable to a degree to which among individuals it is not" 27 . This unique situation is premised on the fact that security within the State is provided by a Leviathan, thus allowing States to prosper through economic self-sufficiency, in a situation beyond the Hobbesian state of nature where they are less vulnerable to external attack.

The manner in which the international society functions as an anarchist system is premised on "a sense of common interests in the elementary goals of social life" which are then manifest as rules. Bull turns to consider some of these rules which "provide precise guidance as to what behaviour is consistent with these goals". The first set of rules, which he calls 'constitutional normative principles' identify the "idea of a society of states, as opposed to such alternative ideas" such as a universal empire. Second, to these rules are those which Bull calls minimum 'rules of co-existence', touching on limitation on the use of force, both to States and by States, to pacta sunt servanda, and respect for each others domestic jurisdiction. The third set of rules are those touching on 'cooperation' and presuppose an established order at the primary and secondary level of normative principles and peaceful co-existence allowing for exchange in areas such as economic, cultural, social and political.

Bull goes on to explain, in terms rather familiar for international jurists that interpretation of rules within the international society is based on self-interpretation, enforcement on self-help, and change of rules through action-reaction of States. The rules which States have crafted are established by mutual consent and in the common interest but place self-imposed limits on States by projecting into the future a "clear conception of the kind of conduct" which is required within the international society. ${ }^{28}$ This first layer of solidarity is then built upon by what Bull calls institutions, namely, balance of power, international law, diplomacy war, and Great Power cooperation; those practices which move towards common goals. They are, in Bull's words: "an expression of the element of collaboration" which gives "substance and permanence to [State] collaboration in carrying out the political functions of the international society", while moderating their "tendency to lose sight of common interests". ${ }^{29}$ It is on this basis that Bull sees an anarchical society functioning at the international level, as a society which has come to a functional understanding of the common good; and agreement on the rules and institutions which link States together while ensuring that they are not subordinated to a common authority.

\section{Bull on International Law}

As noted above, for Bull, one such institution which creates the international order is international law. Bull interacts with international law to demonstrate its place within an anarchical order; but also that international law is indeed an anarchical legal system which functions not on the basis of an Austinian notion of 'a command by a sovereign backed by threat of sanction'; but on a Hartian basis, as a non-coercive legal order. The starting point for Bull is to consider the nature of international law. In his The Anarchical Society, Bull devotes a chapter to international law as an institution which contributes to international order; wherein he takes issue with John Austin that a essential element of law is "the product of sanctions, force or coercion",

\footnotetext{
Hedley Bull, op. cit. n. 14, pp. 50-51 and 45.

28 Id., p. 71.

29 Id., p. 74
} 
and that without an overarching sovereign one can not truly speak about international law but merely "positive international morality". Bull notes that those that reject this approach consider the issue from two perspective, first, those such as Hans Kelsen, who, while accepting that no Leviathan exists over the international system, claim that international law remains grounded in coercion; and second, those, like H.L.A. Hart, who "question the assumption that law has to be defined in terms of coercion". 30 Bull, who attended Hart's classes at Oxford, is drawn to the latter approach, wherein law is to be conceptualised as the "union of primary and secondary rules" which displaces coercion as a basis of the concept of law. In this Hartian approach, Bull sees the possibility to think of law - indeed international law - as functioning within a decentralised system of cooperation. ${ }^{31}$

Hart rejects in large part the domestic analogy, taking on the "adverse comparison of international law to municipal law", and challenging the "theory that law is essentially a matter of orders backed by threat". For Hart, we must step away from an understanding of the concept of law which is synonymous with law as its exists in municipal systems; instead we should understand that law beyond its external coercive dimension, has built in to it an internal element wherein individuals internalise the "rules accepted as guiding standards of behaviour". Hart continues, "once we free ourselves from the predictive analysis and its parent conception of law as essentially an order backed by threats, there seems no good reason for limiting the normative idea of obligations to rules supported by organized sanctions". Hart makes plain that the distinction between the individual within a domestic order and States in international relations is fundamentally different, wherein the necessity of sanctions is dissimilar. As a result, the rules of international law need not be "enforced by any central organ".

Yet what these rules require is thought and spoken of as obligatory; there is general pressure for conformity to the rules; claims and admissions are based on them and their breach is held to justify not only insistent demands for compensation, but reprisals and countermeasures. When the rules are disregarded it is not on the footing that they are not binding; instead efforts are made to conceal the facts. $[\ldots]$

Yet that even so much may be secured shows that no simple deduction can be made from the necessity of organized sanctions to municipal law, in its setting of physical and psychological facts, to the conclusion that without them international law, in its very different setting, imposes no obligations, is not 'binding', and so not worth the title of 'law'. ${ }^{32}$

For Bull, what is important about Hart, is not the concept of primary and secondary rules (indeed Hart is unwilling to apply his concept of law to international law as he fails to see in it secondary, rules of change - a failure which international legal scholars have deemed "inadequate or inept drafting". ${ }^{33}$ ); instead it is that law itself need not be backed by threat. Rather Bull points to the fact that for those in the international sphere whose activities concern international law there is "the

\footnotetext{
30 Hedley Bull, "Society and Anarchy in International Relations", Alderson and Hurrell, op. cit. n. 1, p. 92 .

For Hart, primary rules or 'rules of recognition' are those which govern the conduct (acts or omissions) of those to whom the law applies; while secondary rules or 'rules of change' are those which govern the manner in which primary rules are created, altered or terminated. See H.L.A. Hart, The Concept of Law, 1961; and more specifically his final chapter devoted to international law.

32 Id., pp. 212-214.

33 See Ian Scobbie, "Wicked Heresis or Legitimate Perspectives? Theory and International Law", Malcolm Evans, International Law, 2006, pp. 87.
} 
assumption that the rules with which they are dealing are rules of law. [... "The fact that these rules are believed to have the status of law", Bull writes, "makes possible a corpus of international activities that plays an important part in the working of international society". ${ }^{34}$

That Hedley Bull was steeped in the writings of international jurists is plain. In their introduction to a book dedicated to the writings of Bull, Kai Alderson and Andrew Hurrell note that:

It is clear that Bull's early work in international relations involved intense and close study of the major figures in the history of international law. He gave lectures on Suarez, Gentili, Grotius, Pufendorf, Vattel and of course, centred many of his early publications around both Grotius and the contrast between Grotius and Oppenheim. His papers contained details notes on the major figures of the classical nineteenth- and twentieth-century international law, including: T. E. Holland, W.E. Hall, James Lorrimer, Henry Wheaton, Robert Phillimore, John Westlake, Travers Twiss, and, of course, Lassa Oppenheim himself. There are also detailed (often extremely detailed) notes on a very wide range of twentieth-century legal writers, including Alexandrowicz, Schiffer, Schwarzenberger, Henkin, Kotzsch, Best, Falk, MacDougal and Feliciano, Wright, Junz, Higgins, Friedman, Brierly, Corbett, Kelsen, Lanheer, O’Brien, Stone, Raz, Baade, Casteñeda, Bozeman, and Röling. [...] In Oxford he gave a 12-week lecture series on 'International Law in a Fragmented World'. ${ }^{35}$

In considering the international system, Bull, following on from Hart, points to coercion as being but one reason why States obey international law. States, Bull writes, "obey international law because of habit and inertia; they are, as it were, programmed to operate within the framework of established principles". $\mathrm{He}$ continues: where "conformity with the law derives from deliberation or calculation, it results from motives of three sorts":

First, obedience may be the consequence of the fact that the action enjoined by the law is thought to be valuable, mandatory, or obligatory, apart from its being legally required, either as and end in itself or as a part of , or a means to, some wider set of values. [...]

Second, obedience may result from coercion, or the threat of it, by some superior power bent on enforcing the agreement. Agreements that are observed chiefly for reason of this sort [...] are exemplified by the acceptance of peace treaties by vanquished states at the time of their defeat and for as long a period thereafter as they remain too weak to challenge the verdict of war.

Third, obedience may result form the interest a state perceives in reciprocal action by another state or states. Agreements and principles restring on this sense of mutual interest [...] are exemplified by the most central principles of international law, such as mutual respect for sovereignty, the keeping of promises and the laws of war.

Bull concludes this consideration by saying that the "importance of international law does not rest on the willingness of states to abide by its principles to the determinant of their interest, but in the fact that they so often judge it in their interests to conform to it". 36

Bull's conception of an international society is manifest in rules having been developed out of common interest with many of these rules coalescing into international law:

Hedley Bull, op. cit. n. 14, p. 136.

Alderson and Hurrell, op. cit. n. 1, pp. 29-30.

Hedley Bull, op. cit. n. 14, pp. 139-140. 
It is not uncommon for a rule to emerge first as a operational rule, then to become established practice, then to attain the status of a moral principle and finally to be incorporated in a legal convention: this appears to have been the genesis, for example, of many of the rules now embodied in multilateral treaties or conventions concerning the laws of war, diplomatic and consular status, and the law of the sea. ${ }^{37}$

As international law is the solidification of certain rules of common interest, the role which international law plays in contributing to the anarchical international order is manifest. "The first function of international law" Bull writes, "has been to identify, as the supreme normative principle of the political organisation of mankind, the idea of a society of sovereign states". Amongst these set of rules then are those establishing the State as the main subject of international law, the manner in which consent is established through the sources of law, and the rules laying out State responsibility. The second, has been to state the rules of coexistence, that is those proscribing the use of force, treaty rules, and the "rules relating to sovereignty and independence". Finally, the third function of international law is "to help mobilise compliance with the rules of international society", be they laws established under Bull's rules of coexistence or rules of cooperation. ${ }^{38}$

With the growth of legal rules of cooperation during the United Nations era, one witnesses the establishment of not only a functional anarchical system of law, but one which is flourishing. International law then, with its lack of central authority and the primacy of cooperation over coercion, is quintessentially anarchic: it is a functioning anarchical legal order. Inherent within any such an anarchical system, however would be the question of dealing with those who transgress the law. For Bull the issue of transgression is not that important. He first observes that there "is no doubt that there exists a substantial degree of coincidence as between actual international behaviour and the behaviour prescribed by the rules of international law". Shadowing the words of Louis Henkin, Bull continues, saying that if a meaningful study of the obedience of the rules of international law could be undertaken "it might be expected to show that most states obey most agreed rules of international law most of the time". 39 For Bull what is important is not violations of international law, but the manner in which these touch on the efficacy of the legal system. So Bull says that "violation of a particular rule usually takes place against the background of conformity with other rules of international law". Bull notes that States will go out of their way to demonstrate, but for the current breach, that they consider themselves and other States bound by the rule at hand. ${ }^{40} \mathrm{He}$ accepts that States will obey international law for various reasons including "habit and inertia" and that States often obey the law for "ulterior motives", yet he retorts that the importance of "international law does not rest on the willingness of states to abide by its principles to the determinant of their interests, but in the fact that they so often judge it in their interest to conform to it". ${ }^{41}$

For Hedley Bull then, international law carries out a specific function with the international system, that is: "identifying the idea of a society of states as the operational principle of world politics, stating the basic rules of coexistence and facilitating compliance with those and other rules". When Bull was writing in the mid-1970s, he saw the prominence of international law as a reflection of a time of stress within the international order, wherein flux in the system had been created by

Id., p. 67.

Id., pp. 140-141.

Id., p. 137.

Id., pp. 137-139.

Id., pp. 139-140. 
the decolonisation process and the east/west schism brought on by the Cold War. As a result, international law did not strengthen the international order, it simply stabilised it, ensuring that the State system would be preserved. ${ }^{42}$

This understanding of the role and function of international law has been taken up by the natural successor to Bull, Andrew Hurrell, in his 2007 On Global Order, wherein he applies the approach of the English School "to the conditions of global politics in the early years of the twenty-first century". Thus, Hurrell is unwilling to accept that the international system is based on atomised States; instead the system "is a historically created and evolving, structure of common understandings, rules, norms and mutual expectations". Within that system international law finds its place as an institution which plays its part in shaping the nature of the system and the manner in which the system can evolve. ${ }^{43}$

Hurrell considers the place of international law within the international order in a Chapter entitled "The Anarchist Society Revisited". There he speaks of the centrality of consent to the international legal order wherein States concede part of their sovereignty to international law to allow for peaceful coexistence. Hurrell notes that "international law is interpreted as a horizontal public order within which no sovereign would submit except to those rules to which it had consented". On that basis, sovereignty cannot by definition be unconditional and can only be meaningful if it is recognized by others". 44 For Hurrell, contemporary international law has moved on from its basis as being exclusively the domain of States; its impact is far larger as its contributes "to legitimacy and obligation and to the continuum of legality from informal to more formal norms, as a well as its creative, generative, and constitutive influence on international political practice". ${ }^{45}$ This results, in part, from the complexity which has emerged created by the ever increasing number of fora and actors involved in the law-making process and the areas covered by international law and the soft-law of international governance.

To this day, proponents of the English School of International Relations engage with the 'anarchy problematique' seeking to explain how the international system functions in the absence of a central authority and in so doing seek to demonstrate the role which international law plays as an institutions of international order. This then is one manner in which an anarchist thinker might find international law interesting. The other, which we turn to now, is manifest in the approach to international law which Noam Chomsky has taken; wherein he interprets the international law in a manner which seeks to reveal its weakness so as to turn it against itself.

\section{Noam Chomsky}

Noam Chomsky (1928 -) is an American academic who revolutionised the study of linguistics through the development of an approach to syntax based on generative grammar. He is a prominent critic of United States foreign policy and one of the leading contemporary thinkers of anarchism. He spent his academic career at the Massachusetts Institute of Technology where he is Institute Professor and Professor of Linguistics (Emeritus).

\section{Chomsky on Anarchism}

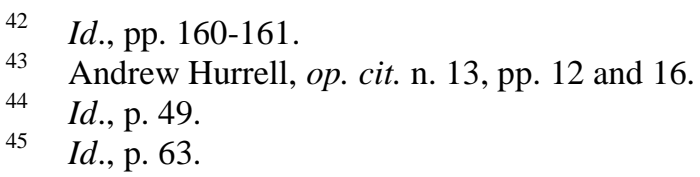


By contrast to Hedley Bull, Noam Chomsky's interest in anarchism is to be found in its manifestations at the domestic level. For Chomsky, anarchism is "formless and utopian, though hardly more so than the inane doctrines of neoliberalism, MarxismLeninism, and other ideologies"46. He considers that there are too many different currents of anarchism to develop a general theory, and points to the historian Rudolph Rocker who notes that anarchism is not "a fixed, self-enclosed social system but rather a definite trend in the historic development of mankind, which [...] strives for the free unhindered unfolding of all the individual and social forces in life":

Even freedom is only a relative, not an absolute concept, since it tends constantly to become broader and to affect wider circles in more manifold ways. For the anarchist, freedom is not an abstract philosophical concept, but the vital concrete possibility for every human being to bring to full development all the powers, capacities, and talents with which nature has endowed him, and turn them to social account. The less this natural development of man is influenced by ecclesiastical or political guardianship, the more efficient and harmonious will human personality become, the more will it become the measure of the intellectual culture of the society in which it has grown ${ }^{47}$.

To this Chomsky asks what value is there is in "studying a "definite trend in the historic development of mankind' that does not articulate a specific and detailed social theory"?; and answers as follows:

many commentators dismiss anarchism as utopian, formless, primitive, or otherwise incompatible with the realities of a complex society. One might, however, argue rather differently: that at every stage of history our concern must be to dismantle those forms of authority and oppression that survive from an era when they might have been justified in terms of the need for security or survival or economic development, but that now contribute to - rather than alleviate - material and cultural deficit. If so, there will be no doctrine of social change fixed for the present and future, nor even, necessarily, a specific and unchanging concept of the goals towards which social change should tend. Surely our understanding of the nature of man or of the range of viable social forms is so rudimentary that any far-reaching doctrine must be treated with great scepticism, just as scepticism is in order when we hear that 'human nature' or 'the demands of efficiency' or 'the complexity of modern life' requires this or that form of oppression and autocratic rule ${ }^{48}$.

Chomsky then provides what he considers the expression of the "single leading idea within the anarchist tradition" as expressed by Mikhail Bakunin (1814-1876) when, in writing about the Paris Commune, he identifies himself as fanatic lover of liberty:

a liberty consists in the full development of all the material, intellectual and moral powers that are latent in each person; liberty that recognizes no restrictions other than those determined by the laws of our own individual nature, which cannot properly be regarded as restrictions since these laws are not imposed by any outside legislator beside or above us, but are immanent and inherent, forming the very basis of our material, intellectual and moral being - they do not limit us but are the real and immediate conditions of our freedom ${ }^{49}$.

For Chomsky's understanding of anarchism he turns to Rudolf Rocker who "describes modern anarchism as the confluence of the two great currents which during and since the French Revolution have found such characteristic expression in the intellectual

\footnotetext{
46 See "On Anarchism", Noam Chomsky interviewed by Tom Lane, 23 December 23, 1996, available at: www.chomsky.info/interviews/19961223.htm.

47 Noam Chomsky, "Notes on Anarchism (1970)", Chomsky on Anarchism, 2005, p. 118.

48 Id., pp. 118-119.

$49 \quad$ Id., pp. 121-122.
} 
life of Europe: Socialism and Liberalism"50. If we unpack this type of anarchism which Chomsky ascribes to - libertarian socialism - it has its roots in liberal philosophers of the Enlightenment, in particular, Wilhelm von Humboldt's 1792 The Limits of State Action. For Humboldt, libertarianism is focused on resisting "the encroachment of coercive state power"; but as Chomsky points out, in the preindustrial capitalist age, this was the only true power base: "I mean, Humboldt takes for granted that individuals are roughly equivalent in their private power, and that the only real imbalance of power lies in the centralized authoritarian state, and individual freedom had to be sustained against its intrusion - the State or the Church. That's what he feels one must resist" ". Chomsky continues: my "personal visions are fairly traditional anarchist ones", but while pointing to liberalism, he notes "I do not mean the version of classical liberalism that has been reconstructed for ideological purposes, but the original, before it was broken on the rocks of rising industrial capitalism, as Rudolf Rocker put it in his work on anarcho-syndicalism 60 years ago rather accurately, I think" ${ }^{\text {. }}$.

What Chomsky then does is to disassociate himself from the liberalism of Locke, Mills, and Rousseau which attaches itself to property and thus justifies a capitalist system which has "increasingly been taken over by vast institutions of private tyranny that are about as close to the totalitarian ideal as any that humans have so far constructed",53. "With the development of industrial capitalism", Chomsky explains, the accumulation of wealth by individuals is "a new and unanticipated system of injustice" which emerged based on "classical liberal ideals that were perverted into an ideology to sustain the emerging social order" $"$.

This libertarian element then is to be combined with a type of socialism to be understood as being in juxtaposition to 'authoritarian' socialism of the type promoted by the Bolsheviks and put in place by Lenin. A type of socialism which seeks to capture the State apparatus and create a 'socialist' revolution through an elite vanguard. It was here that Bakunin, the so-called 'father of modern anarchism' split with Karl Marx, as he anticipated a 'Red bureaucracy' which would assist the new class of intellectual elite in subverting the popular struggle by introducing a "dictatorship of the proletariat" ". Thus, for the libertarian socialist, the State must be destroyed and replaced by democratic structures based on free consent, not on authoritarian, top-down, dictates. As Chomsky notes: "The question of conquest or destruction of state power is what Bakunin regarded as the primary issue dividing him from Marx. In one form or another, this problem has arisen repeatedly in the century since, dividing 'libertarian' from 'authoritarian', socialists"

What then would replace the State? For those like Kropotkin and Chomsky, the full development of the individual is premised on a future system of governance which is "controlled by the participants, not by those in a position to give orders" The vision of that society, Chomsky writes, is animated by "what we actually do, a

\footnotetext{
$50 \quad I d .$, p. 123.

51 Noam Chomsky, "The Relevance of Anarcho-syndicalism (1976)", Chomsky on Anarchism, 2005, p. 135.

Noam Chomsky, “Goals and Visions (1996)", Chomsky on Anarchism, 2005, p. 191.

53 Id., p. 191.

54 Noam Chomsky, "Notes on Anarchism (1970)", op. cit. n. 47, p. 118.

55 See "Anarchism", Noam Chomsky interviewed by David Dobereiner, John Hess, Doug Richardson \& Tom Woodhull, in C. P. Otero (ed.), Language and Politics, January, 1974; available at www.chomsky.info/interviews/197401--.htm.

56 Noam Chomsky, "Notes on Anarchism (1970)", op. cit., n. 47, p. 121.

57 Noam Chomsky, “Anarchism, Marxism and Hope for the Future (1995)", id., pp. 181-182.
} 
society in which a decent human being might want to live" ${ }^{, 58}$. For Chomsky this future is based on a concept of human nature wherein anarchy releases "intrinsic human characteristics that provide the framework for intellectual development, the growth of moral consciousness, cultural achievement, and participation in a free community"59. It is here then that Chomsky projects his vision of an anarchist society:

Beginning with the two modes of organization and control, namely organization and control in the workplace and in the community, one could imagine a network of workers' councils, and at a higher level, representation across the factories, or across branches of industry, or across crafts, and on to general assemblies of workers' councils that can be regional and national and international in character. And from another point of view, one can project a system of government that involves local assemblies - again, federated regionally, dealing with regional issues, crossing crafts, industry, trades, and so on, and again at the level of the nation or beyond ${ }^{60}$.

Yet the participation in governance would be transitory and would have individuals participating in various levels of government on a rotational basis. In this way power would be utilised not in a hierarchical, authoritarian, manner but would be legitimatised as being justifiable, having been determined as so by small, democratic, groups.

For Chomsky and within his stream of anarchism, this type of governance not only requires a radical reformulation of the political system, but a dismantling of the economic system, which "is not a fit system for the mid-twentieth century", as it is incapable of meeting basic human needs and is instead geared towards the "concept of competitive man who seeks only to maximise wealth and power, who subjects himself to market relationships, to exploitation and external authority" which is, Chomsky states: "antihuman and intolerable in the deepest sense" ${ }^{\text {" }}$. Chomsky makes plain that the "extraordinary power that corporations and financial institutions enjoy" was not by chance, it "was crafted by courts and lawyers in the course of the construction of a developmental state that serves the interests of private power" ${ }^{\prime \prime}$. As such, the capitalist system, like the State system, is illegitimate having been created to benefit the few at the expense of the many, and thus should revert to the hands of the many to decide, on the democratic basis of an anarchist society, how best to use the resources of the planet.

As Chomsky relates:

The core principles as far as I understand it - anarchism covers a wide range, you can't encapsulate it in formulas - but there seems to be a thread that runs all the way through it. It's basically a scepticism about any form of authority, or domination, or submission. The basic idea is that domination and hierarchy are not self-justifying. They have to justify themselves and the burden of proof is theirs to bear. And if they can't justify themselves, then they should be dismantled. And that covers everything from personal relations to international relations. ${ }^{63}$

In essence then Chomsky's traditional understanding of anarchism and one he subscribes to, seeks to dismantle structures of hierarchy and authority if they can not be justified; that the State and the economic system are based on coercion and are not

58 Noam Chomsky, "Goals and Visions (1996)", id., p. 190.

59 Noam Chomsky, "Language and Freedom (1970)", id., p. 114.

60 Noam Chomsky, "The Relevance of Anarcho-syndicalism (1976)", id., p. 137.

61 Noam Chomsky, "Language and Freedom (1970)", id., p. 114.

62 Noam Chomsky, "Goals and Visions (1996)", id., p. 192.

63 Noam Chomsky, "Anarchism, Council Communism, and Life after Capitalism" in Sacha Lilley (ed.), Captial and its Discountents: Conversations with Radical Thinkers in a Time of Tumult, 2011, p. 237. 
in tune with human nature; nor do they provide a fair or equitably distribution of resources. As Chomsky notes, the question which should always be asked with regard to power and authority is: "Why should I accept it? It's the responsibility of those who exercise power to show that somehow it's legitimate. It's not the responsibility of anyone else to show that it's illegitimate. It's illegitimate by assumption, if it's a relation of authority among human beings which places some above others. That's illegitimate by assumption. Unless you can give a strong argument to show that it's right, you've lost"64.

Where it may be said that Chomsky diverges from typical anarchist thinking is with regard to tactics, as he is not a pure proponent of the dismantling of the State, but in certain situations, sees the need to strengthen it; or better, to strengthen certain elements of the State:

\begin{abstract}
My short-term goals are to defend and even strengthen elements of state authority which, though illegitimate in fundamental ways, are critically necessary right now to impede the dedicated efforts to 'roll back' the progress that has been achieved in extending democracy and human rights. State authority is now under severe attack in the more democratic societies, but not because it conflicts with the libertarian vision. Rather the opposite; because it offers (weak) protection to some aspects of that vision. Governments have a fatal flaw: unlike the private tyrannies, the institution of state power and authority offer to the despised public an opportunity to play some role, however limited, in managing their own affairs ${ }^{65}$.
\end{abstract}

Chomsky continues, in “today's world, I think, the goals of committed anarchist should be to defend some state institutions from the attack against them, while trying at the same time to pry them open to more meaningful public participation - and ultimately, to dismantle them in a much more free society, if the appropriate circumstances can be achieved",66.

\title{
Chomsky on International Law
}

Despite the typical rejection of law by anarchist thinkers, Chomsky's 'modified' anarchical thinking explains why he is willing to engage in using international law to critique American foreign policy despite the apparent contradiction in supporting this mechanism which reinforces the status quo of a Statist system. The starting point for considering Chomsky's use of international law is his participation in the 1971 Symposium on war crimes which considered Telford Taylor's book - Taylor was chief counsel for the prosecution at Nuremberg and retired as a US Brigadier General - Nuremberg and Vietnam: An American Tragedy ${ }^{67}$. Chomsky's review of Taylor's book, which appears in the Yale Law Journal, is centred on two items: the legality of the use of force in Vietnam and the issue of war crimes; two themes which he returns to throughout his foreign policy writings. Chomsky considers that Nuremberg and Vietnam is "conservative in assumptions and narrow in compass" though "Taylor's investigation leads to strong conclusions":

He comes close to suggesting that the military and civilian leadership of the United States during the period from 1965 to the present [1971] are liable to prosecution as war criminals, under the

64 See "Activism, Anarchism, and Power", Noam Chomsky interviewed by Harry Kreisler, 22 March 2002, available at: www.chomsky.info/interviews/20020322.htm.

65 Id., p. 193.

66 Id., p. 194.

67 That Review Symposium, it might be mentioned included the Philosopher Marshall Cohen and Princeton University Professor of Law, Richard Falk. 
standards of Nuremberg. No less controversial are the self-imposed limitations on his study. In many respects, Taylor's book offers a convenient point of departure for an investigation of the issues of legality and justice ${ }^{68}$.

Chomsky then considers Taylor's discussion of crimes against the peace and his observation that "the justification for the American intervention in Vietnam can only be Article 51 of the United Nations Charter". While Taylor focuses on the possibility of US violations of the use of force when acting in tandem with South Vietnam against North Vietnam, for Chomsky, "these charges constitute only part of the case":

A much more serious charge is that the United States has engaged in aggressive warfare in South Vietnam in violations of the United Nations Charter concerning the use of force. These charges are based on military actions taken against an insurgency which the United States recognized to be popular and successful - far more popular than the government it had installed and maintained, which had lost the war by $1965[\ldots]^{69}$.

In other words, that the United States, having imposed a new regime in South Vietnam was then invited by it to suppress a popular-based insurrection.

Turning to the legal analysis, Chomsky uses as his foil Thomas Franck and his article that appeared in the 1970 edition of the American Journal of International Law: 'Who Killed Article 2(4)? or Changing Norms Governing the Use of Force by States ${ }^{70}$. While accepting the premise that Article 2(4) is dead, Chomsky notes that "Franck's discussion seems to me to be flawed by an implicit bias in favour of these powers [re: Cold-War Super Powers] ${ }^{71}$. For Chomsky, the Cold War was not so much about East-West relations but a tacit undertaking by the Super Powers to control their own adopted spheres ${ }^{72}$; and thus he seeks to cut through this first level of justification for the use of force, that is: "the great powers' attempts to disguise their interventions on grounds of presumed relations to great power conflict"73. He then focuses on Franck's consideration of "war of agitation, infiltration, and subversion carried on by proxy through national liberation movements" and quotes the following passage in Frank's piece: “One man's war of national liberation is another's aggression or subversion, and vice versa"; so as to put a contrary view forward:

His bias is revealed in that he continually takes the position of the second man: the new kinds of warfare which, he argues, have led to the erosion of Article 2(4) are characterized as wars of infiltration and subversion carried out by proxy. If, taking the contrary view, these should be characterized as imperial interventions to repress movements of national liberation, then it follows that the erosion of Article 2(4) has not been caused by the "changing realities of postwar quartercentury' but primarily by the postwar forms of traditional behaviour of great powers" 74 . By

\footnotetext{
68 Noam Chomsky, "The Rule of Force in International Affairs", Yale Law Journal, Vol. 80, 1971, p. 1456.

$69 \quad$ Id., p. 1486.

70 Thomas Franck, "Who Killed Article 2(4)? or Changing Norms Governing the Use of Force by States", American Journal of International Law, Vol. 64, 1970, pp. 809-837. See also Louis Henkin, "The Reports of the Death of Article 2(4) Are Greatly Exaggerated", American Journal of International Law, Vol. 65, 1971, pp. 544-548.

71 Noam Chomsky, op. cit. n. 68, p. 1486.

72 See Noam Chomsky, "Cold War: Fact and Fancy", Deterring Democracy, 1992, pp. 9-68, where he notes at p. 28: "Putting second-order complexities to the side, for the USSR the Cold War has been primarily a war against its satellites, and for the US a war against the Third World".

73 Noam Chomsky, op. cit. n. 68, p. 1487.

$74 \quad$ Id., p. 1487.
} 
begging the question in the particular way he does, Franck takes his stand, without argument or even explicit assertion, on the side of the great powers ${ }^{75}$.

Chomsky ends by noting that "we must conclude that there is no strikingly new factor in the postwar era that led to the erosion of Article 2(4)"; instead that the erosion can be laid squarely at the feet of the Superpowers.

Having considered Chomsky's approach to jus ad bellum, consideration now turns jus in bello and the issue of war crimes in Vietnam. Here Chomsky is not so concerned with US violations of the grave breaches provisions of the Geneva Conventions or Hague Law, though he does mention Taylor's determination that "routine destruction of villages by American firepower and ground sweeps and the forced evacuation of populations" are "of doubtful legality" and that "reprisals against villages harbouring Vietcong" are "flagrant violations"76. Instead he takes issue with the law itself and its failure to take into consideration the means and methods of warfare used by liberation movements - that very element of the laws of war which, as a result of Vietnam War, was addressed in the 1977 protocols to the Geneva Conventions. Chomsky notes that Taylor makes plain that at Nuremberg, it was determined that "a civilian who aids, abets, or participates in the fighting is liable to punishment as a war criminal" and though this seems harsh, it is established law. This in juxtaposition to the law which "does not apply to aerial bombardment of towns and villages in a effort to break the enemy's will or to deny him material resources" which Chomsky writes, "comes very close to branding 'people's war' illegal",77.

"These laws, so understood, are the weapon of the strong, and are of no moral force or validity", Chomsky notes, and continues:

It is a political decision to accept an interpretation of the law which holds that a government installed and maintained by a foreign power [...] has the right to call upon this foreign power to suppress an insurgency that has gained such extensive political support that insurgents are indistinguishable from the population, and which holds that civilian participants in the insurgency are war criminals ${ }^{78}$.

He then concludes, "If international law has nothing to say about this (except that civilians aiding the resistance are war criminals), then its moral bankruptcy is revealed"79. As the law stood at the time, Chomsky is right to be critical, as in this case, international law was indeed reserved for the State, as no privileges were granted to combatant involved in guerrilla warfare until 1977 and the elaboration of Protocol I to the Geneva Conventions. ${ }^{80}$ Ultimately, Chomsky's focus on aggression

75 Id., pp. 1487 and 1487-1488.

76 Id., p. 1463.

77 Id., p. 1464 . Chomsky presses the point at p. 1465 by stating:

These laws, Taylor maintains, condemn as war criminals the civilians who take up arms against a foreign enemy or its local protégés; such civilians are 'undeniably in violation' of the laws of war. But with regard to the American pilots who have destroyed towns and villages and devastated farmland and forest, driving millions from their homes and killing unknown numbers throughout Indochina, or to those who planned this policy, the laws of war have little to say.

78 Id., p. 1465.

79 Id., p. 1468.

80 Article 44(3) of the 1977 Protocol I to the Geneva Conventions established that: 
and war crimes is a recurring theme in his work, yet over time, as we shall see, he has become less critical of international law per se and instead moves to utilise it as part of his arsenal of critique levelled at the foreign policy of the United States of America.

In his 1996 Power and Prospects Chomsky considered international law in general terms: "I am not really concerned here with the technicalities, but rather the principles that underlie them". Chomsky explains why he utilises international law as a reference point for analysis: "I will discuss the backgrounds in international law only insofar as they reveal, as I think they do, the principles to which decent people should be committed, and which they should compel their governments to observe" ${ }^{\nexists 1}$.

In essence, Chomsky moves to support and promote international law for tactical reasons, as a Statist mechanism which, although fundamentally illegitimate, acts to highlight American violations of the use of force and transgressions of the Nuremberg Principles. As such, Chomsky is not interested in international law as an anarchical system - nothing in his writings reveals that he makes the connection - instead he sees international law as a forum for establishing a burden of justification of the exercise of State power as against a set normative markers. By revealing violations of international law, he develops an immanent critique, seeking to bring the very system of international law in to question. In so doing, Chomsky stumbles upon the justification of public order as a basis of jus cogens imperatives. That is to say: that peremptory norms exist because their violation brings the very State system into question. $^{82}$

That tactical move on Chomsky's part resulted from the International Court of Justice's handling of the Nicaragua case. In his 1985 Turning the Tide, Chomsky pointed to the 1984 International Court decision on jurisdiction which found against the United States and noted American refusal to acknowledge or accept the Court's jurisdiction in the lead up to that determination ${ }^{83}$. Quoting with irony New York Times columnist Anthony Lewis, who criticised US President Reagan's unwillingness to accept the Court's jurisdiction by noting the President failed "to understand what

In order to promote the protection of the civilian population from the effects of hostilities, combatants are obliged to distinguish themselves from the civilian population while they are engaged in an attack or in a military operation preparatory to an attack. Recognizing, however, that there are situations in armed conflicts where, owing to the nature of the hostilities an armed combatant cannot so distinguish himself, he shall retain his status as a combatant, provided that, in such situations, he carries his arms openly:

(a) during each military engagement, and

(b) during such time as he is visible to the adversary while he is engaged in a military deployment preceding the launching of an attack in which he is to participate.

81 Noam Chomsky, Power and Prospects: Reflections on Human Nature and the Social Order, 1996, pp. 205 and 208-209.

See generally the first chapter of Alexander Oranhelashvili, Peremptory Norms in International Law, 2006; and more specifically, the reproduction of Judge Mareno-Qunintana's Separate Opinion in the Guardianship of Infants case reproduced at p.28, which reads:

International public order operates within the limits of the system of public international law, when it lays down certain principles such as the general principles of law of nations and the fundamental rights of States, respect for which is indispensable to the legal coexistence of the political unites which make up the international community. ... These principles - we are all quite familiar with them because they are very limited - and these rights, too, have a peremptory character and universal scope.

83 See International Court of Justice, Case concerning Military and Paramilitary Activities in and against Nicaragua, 26 November 1984. 
the rule of law has meant to this country" ${ }^{\prime 4}$; Chomsky digs into the Orwellian memory-hole to produce a seventy-year old example which he notes, re-enacts the events taking place at The Hague:

In 1907, at US initiative, a Central American Court of Justice was established to adjudicate conflicts among the American States. A few years later, the Court was destroyed by US refusal to recognize its decisions with regard to US interventions in Nicaragua ${ }^{85}$.

As Chomsky points out in Manufacturing Consent, "There are, to be sure, differences between the earlier case and today's [...]. Now Nicaragua is not under marine occupation - merely under military attack by a U.S. mercenary army called 'freedom fighters' [re: Contras]; and the United States is not powerful enough to simply disband the World Court" incident breaks no new ground in the history of US lawlessness" ${ }^{\prime 87}$. On many occasions since the 1986 Judgment in the Nicaragua case, Chomsky has referred back to the episode as an example of the manner in which the United States sees itself as not being bound by the same rules as other States ${ }^{88}$.

Turning to more recent writings, Chomsky believes that the United States of America is in a privileged position wherein it seeks a "self-exception from core principles of international law" while at the same time believing itself capable of creating "new norms of international law" $"$. With regard to the first of these, that the United States of America can self-except itself "from core principles of international law", Chomsky considers the "spectrum of articulate opinion on the resort to military force" whereby one part of the continuum considers the Charter, to the UN HighLevel Panel and to the 2005 UN World Summit, while the "rest of the spectrum [it should be said - in the United States] basically adopts the principle that the United States is uniquely exempt from international law and jurisdiction, and is accordingly

84 Noam Chomsky, Turning the Tide: U.S. Intervention in Central American and the Struggle for Peace, 1985, p. 91.

${ }_{85}$ Id., p. 91. Although the case was not about the legality of the American presence in Nicaragua, it did relate to a treaty signed while under occupation which granted the United States the right in perpetuity to built a canal through Nicaragua. The Central American Court found that this agreement violated the rights of both Costa Rica and El Salvador. See Jean Allain, "Central American Court of Justice", A Century of International Adjudication: The Rule of Law and its Limits, 2000, pp. 67-92.

86 See James Peck (ed.) Noam Chomsky Reader, 1987, p.125.

87 Noam Chomsky, op. cit. n. 84, p. 91. Chomsky's esteem for international law grows as he moves to consider the International Court's decision on the merits, using irony once more to get his point across:

The effectiveness of the state-corporate propaganda system is illustrated by the fate of May Day, a worker's holiday throughout the world that originated in response to the judicial murder of several anarchists after the Haymarket affair of May 1886, in a campaign of international solidarity with the U.S. workers struggling for an eight-hour day. In the United States, all has been forgotten. May Day has become 'Law Day,' a jingoist celebration of our '200-year-old partnership between law and liberty' as Ronald Reagan declared while designating May 1 as Law Day 1984, adding that without law there can be only 'chaos and disorder'. The day before, he had announced that the United States would disregard the proceedings of the International Court of Justice that later condemned the U.S. government for its 'unlawful use of force' and violations of treaties in its attack against Nicaragua

See Noam Chomsky, Necessary Illusions: Thought Control in Democratic Societies, 1989, pp. 29-30.

${ }_{88}$ See for instance, Noam Chomsky, Pirates and Emperors, Old and New, 1986, pp. 123-124; Deterring Democracy, 1992, p. 315; Power and Prospects, 1996, p. 206; and Failed States, 2006, p. 35.

${ }_{89}$ See Noam Chomsky, Failed States: The Abuse of Power and the Assault on Democracy, 2006, pp. 65-69 and 94-101. 
entitled to resort to any measures it chooses to respond to a challenge to its 'power, position, and prestige' $[\ldots]^{\prime, 90}$.

As an example of this self-exemption, Chomsky refers back to the Nicaragua case and, though pointing out the US multilateral reservation to the opinion clause system of the International Court of Justice, notes that the Court "restricted its deliberations to customary international law and a bilateral US-Nicaragua treaty" and even "on these narrow grounds, the court charged Washington with 'unlawful use of force' - in lay language, international terrorism $[\ldots]^{391}$. He concludes rather awkwardly by saying that the "relevant point here is that the court correctly recognized that the United States is self-exempt from the fundamental principles of world order that it played the primary role in formulating and enacting"; though the Court of course rejected this self-exemption principle ${ }^{92}$. Chomsky provides a further example of this notion of self-exemption of core principles of international law, first in regard to consular notice and the successful claim brought before the International Court of Justice by Mexico against the United States ${ }^{93}$. Noting that the Vienna Convention on Consular Relations was first invoked in the Tehran Hostages case, he continues "International law and court judgments are fine, but only when they come out the right way". Chomsky continues:

The basic problem with the World Court and the world, so we learn from UN ambassador John Bolton, is that they misinterpret international law. One of the administration's legal specialists, Bolton writes that 'in the rest of the world, international law and its 'binding' obligations is taken for granted'. But no such binding obligations can apply to the United States. That follows from the fact that the 'accumulating force' of international law interferes with Washington's freedom to act as it chooses and 'will even more dramatically impede us in the future. Treaties are not 'legal' obligations for the United States, but at most 'political commitments'. [...]

The reasoning throughout is straightforward, and is in full accord with what Bush calls 'new thinking in the law of war,' which takes international law and treaties to be 'private contractual rules' that the more powerful party 'is free to apply or disregard as it sees fit': sternly enforced to ensure a safer world for investors [re: WTO and WIPO], but quaint and obsolete when they constrain Washington's resort to aggression and other crimes ${ }^{94}$.

In in a 1999 book Chomsky pronouncing himself generally on international law as a yard stick of assessment. That conclusion brings into sharp relief the tenets of his anarchist approach which mandate that power should not go unchallenged and that, for instance, international law must continuously demonstrate its value by justifying its authority:

Recognized principles of international law and world order, treaty obligations, decisions of the World Court, considered pronouncements of respected commentators - these do not automatically yield general principles or solutions to particular problems. For those who do not adopt the standards of [a] Saddam Hussein, there is a heavy burden of proof to meet in undertaking the threat or use of force. Perhaps the burden can be met, but that has to be shown, not merely proclaimed. [...] The reasons for the actions also have to be assessed - on rational grounds, with attention to historical fact and the documentary record, not simply by adulation of our leaders and the 'principles and values' attributed to them by admirers ${ }^{95}$.

\footnotetext{
90 Id., p. 95. See also Noam Chomsky, A New Generation Draws the Line, 2012, pp. 150-158.

$I d .$, p. 65.

Id., pp. 65 and 66.

93 See International Court of Justice, Case concerning Avena and other Mexican Nationals, 31 March 2004.

94 Noam Chomsky, Failed States: The Abuse of Power and the Assault on Democracy, 2006, p. 68.

95 Noam Chomsky, The New Military Humanism: Lessons from Kosovo, 1999, p. 157.
} 
Having considered Noam Chomsky's use of international law, it is clear that he sees value in its use as a critic of State action. Chomsky's pragmatism in engaging with international law is meant to assist in the implosion of the international legal order by demonstrating its illegitimate nature wherein the powerful do as they wish while the weak must respect the dictates of international law. Chomsky wishes to challenge manifestations of power and hierarchy which appear to be illegitimate; and as such he turns to international law as an object standard to hold States to account. In so doing, he reveals the ultimate paradox of the international order: that the failure of States to respect the principles and precepts manifest in the international legal order leads to the weakening of that public order and within it the seeds of its own destruction.

Noam Chomsky's understanding of international law, it must be said, is often times rudimentary. His polemic nature does get the better of him as he sometimes misrepresents the law in trying to drive the point home. Can we say that the United States can create new norms on the international plane? The rollback of the Bush Administration's 'War on Terror' policies, in regard to the status of prisoners at Guantanamo Bay, to the use of torture, and to other 'innovative' interpretations of international law indicates that, in the long run, norms are established not by imposition by one State but by acceptance through the horizontal system of cooperation in force in the anarchical society. Is the United States self-exempt from fundamental principles of international law? Often times, as Chomsky demonstrates, it thinks it is, but on certain occasions the International Court of Justice has revealed that the pretext of United States' action - and the writings of those legal scholars who seek to justify American actions - has no grounding in international law.

\section{Conclusion}

This study, more than anything has sought to engage seriously with an anarchist thinking and to consider the international system as functioning on the basis of anarchism rightly understood as a decentralised, horizontal system of equal subjects coming together on the basis of cooperation not coercion. It has sought to demonstrate through the writing of Hedley Bull that thinking about the international system as an anarchical society is very much the bread and butter of international relations theorists, but finds limited voice within the scholarly writing of international law. International law however, is an anarchical legal system. As noted in the introduction, for Bull, anarchy is the "central fact of international life and the startingpoint of theorising about it" 96 . Richard Ashley, writing in 1988, states that: "two decades after Bull offered this assessment, nearly every theorist addressing the problem of global collaboration and international order would seem to agree. Among these theorists, the 'fact of anarchy' necessarily occupies the foreground of serious discourse" "97. In the forefront of this discourse have been proponents of the English School, who have sought to demonstrate the role and function which international law plays in international relations, in essence, revealing the law for what it is: a system of law functioning in an anarchic order.

\footnotetext{
96 Hedley Bull, "Society and Anarchy in International Relations", Alderson and Hurrell., op. cit. n. 1, p. 77.

Richard Ashley, "The Powers of Anarchy: Theory, Sovereignty, and the Domestication of Global Life (1988)", James Der Derian (ed), International Theory: Critical Investigations , 1995, p. 94.
} 
For Noam Chomsky, it is his nuanced libertarian socialism which allows him to engage with the precepts of international law as a standard to measure and critique United States foreign policy. Chomsky's pragmatism in engaging with international law, though he considers it fundamentally illegitimate, must be understood as a means of using international law as a manifestation of the State against itself. It is clear that Chomsky, though the foremost anarchist thinker of our day, does not consider international law because it governs an anarchical system - again, there is no acknowledgement on his part of the anarchic ethos of the international system instead, and in line with his general anarchist critique, Chomsky wishes to challenge manifestations of power and hierarchy which appear to be illegitimate; and, as such, he turns to international law as an object standard to hold States to account.

This study, in considering two manners in which an anarchist thinker might find international law interesting provides an opening for consideration of the 'international analogy' to develop: what does the international anarchic system and the place of international law say with regard to the project of an anarchist system being established domestically and the role which law might play within such a society? Further, the study raises the question about theorising about international law and the lack of engagement with the notion of anarchism as a basis of that legal order; whether it be build on the English School or on nineteenth century anarchist thinkers such as Bakunin or Kropotkin. 